\title{
Inovasi Program Kesehatan 24 Jam Dalam Mewujudkan Good Health Care Governance di Kabupaten Bantaeng
}

\author{
Muchlas M. Tahir ${ }^{1}$ \\ Ahmad Harakan ${ }^{2}$

\section{Program Studi IImu Pemerintahan Fakultas IImu Sosial dan IImu Politik Universitas Muhammadiyah Makassar} \\ Email : ahmad.harakan@unismuh.ac.id
}

\begin{abstract}
ABSTRAK
Inovasi pemerintah dalam pelayanan kesehatan merupakan salah satu urusan otonomi yang dimiliki banyak ruang inovasi karena tantangan layanan kesehatan bersifat sangat konpleks ,kompleksitas itulah yang selalu menghasilkan berbagai ide selain menghasilkan kebaruan dalam suatu pembaruan inovasi pemerintah antara lain dalam meningkatkan pelayanan kepada masyarakat baik dipemerintah pusat dan pemerintah daerah. Di tingkat daerah, misalnya disaat ini ada beberapa kabupaten dan kota yang sudah berhasil mengadakan inovasi-inovasi administrasi, sehingga dapat memperbaiki penyelenggaraan pemerintah, serta dapat melayani masyarakat dengan lebih baik. Tetapi kinerja pemerintah daeah dalam melaksanakan pelayanan publik dan meningkatkan pencapaian pembangunan daerah. Jenis penelitian ini adalah penelitian kualitatif (menjelaskan kondisi objek dengan cara-cara ilmia) dengan informasi sebanyak 9 (sembilan) orang yang dipilih berdasarkan pandangan dari penulis bahwa informasi tersebut memiliki pengatahuan dan informasi mengenai masalah yang penulis teliti antara lain: kepala pelayanan kesehatan ,pegawai rumah sakit, masyarakat pengguna layanan(pasien), tokoh masyarakat. Data yang dikumpulkan dengan menggunakan instrumen berupa ; observasi dan dokumentasi serta dikembangkan dengan wawancara terhadap informasi. Hasil penilitian ini menunjukkan bahwa inovasi pemerintah daerah dalam pelayanan kesehatan 24 jam dia Kabupaten Bantaeng bisa dikategorikan pelayanan yang baik dan maksimal, karena berdasarkan aturan-aturan pemerintah itu sendiri dan dirasakan pelayanan terhadap tokoh masyarakat dan pengguna layanan(pasien).
\end{abstract}

Kata kunci : inovasi pemerintah, pelayanan kesehatan, Tata Kelola Pemerintahan yang baik.

\section{ABSTRACT}

Government innovation in health care is one of the affairs of the autonomy that has plenty of space innovation, because the challenges of healt services is very complex, the complexity that always produces a novelty in a newness of innovation the government among other to improve services to the public in both the central government and local government. At the local level, for example, when there are several counties and cities that have successfully entered administrative innovations, so as to improve administration of the government, and can serve the performance of local goverments in implementing publick service and improve the achievement of regional development. This type of research is qualitative research (explain the conditions of the object with scientific ways) with as much information as (nine) persons who have been selected based on the views of the auther that such information has the knowledge and information on issues that I researched, among others: the head of health service s, employee hospitals, service recipients (patients), public figures. Data collected by using instruments such us; observation and documentation and developed with interviewsto information. The results of this study indicate that the local government innovation in healt services can be categorized as the good and the maximum, because according the rules of government itself and perceived service to community and service users (patients).

Keyword: innovation of local government, health services, Good Governance. 
PENDAHULUAN

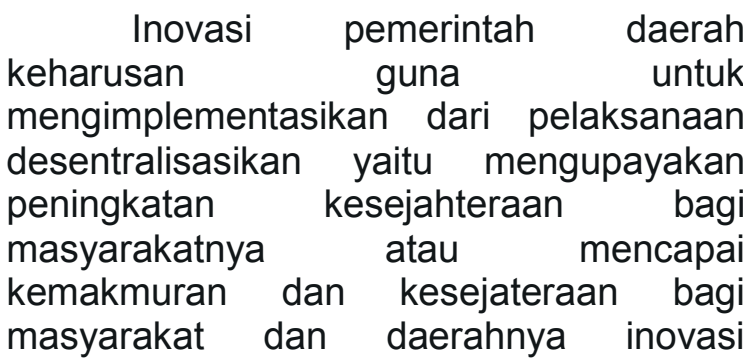
program yang terbukti mampu membawa kemajuan bagi sebuah daerah yang sebelumnya terbelakang menjadi daerah yang maju secara ekonomi dan mampu meningkatkan kesejahteraan masyarakatnya, inovasi adalah merupakan proses yang dimulai dengan keinginan untuk menjadi lebih baik inovasi sangat terkait dengan penemuan dimana secara umum inovasi muncul dari sebuah proses dan dari sebuah perencanaan besar.

Selain itu Pelayanan kepada masyarakat sudah menjadi tujuan utama dalam penyelenggaraan administrasi publik. Di Indonesia penyelenggaraan pelayanan publik menjadi isu kebijakan yang semakin strategis karena perbaikan pelayanan publik di negara ini cenderung berjalan di tempat, sedangkan implikasinya sebagaimana diketahui sangat luas karena menyentuh seluruh ruang-ruang kepublikan baik dalam kehidupan ekonomi, sosial, politik, budaya dan lain-lain (Mahsyar, 2011).

10 tahun terakhir, banyak daerah menunjukkan peningkatan kinerja yang dipicu oleh praktif inovatif inovasi yang didasarkan pada semangat untuk pelayanan public dalam birokrasi perlambat buat apa dipercepat dibidang tata kelola pemerintahan banyak inovasi dilakukan oleh pemerintah daerah antara lain upaya pengembangan system transparansi mekanisme penanganan masyarakat, dan pengembangan forumforum lintas pemengkuh kepentingan dalam rangka meningkatkan partisipasi masyarakat. Pelayanan publik yang berkualitas merupakan tuntutan yang sangat mendasar dalam sistem pemerintahan good governance (Muhammadiah, 2011).

Pelayanan kesehatan sebuah konsep yang digunakan dalam memberikan pelayanan kesehtan kepada masyarakat, yang tujuan utamanya adalah pelayanan preventif (pengcegahan) dan promotif (peningkatan kesehatan) dengan sasaran masyarakat umum,dan setiap upaya yang diselenggarakan sendiri atau secara bersama-sama dalam suatu organisasi untuk memelihara dan meningkatkan kesehatan, mencegah dan menyembuhkan penyakit sertah memulihkan kesehatan perorangan, keluarga, kelompok, dan ataupun masyarakat. Dan pelayanan kesehatan adalah sejatera dari badan, jiwa, sosial memungkinkan setiap orang hidup produktif secara sosial dan ekonomis, upayah kesehatan setiap kesehatan yang dilakukan oleh pemerintah atau masyarakat

Sistem kesehatan di indonesia tidak terlepas dari pembangunan pelayanan kesehatan, intinya pelayanan kesehatan merupakan seluruh aktifitas uang mempunyai tujuan utama untuk mempromosikan mengembalikan dan memelihara kesehatan denagan distribusi yang adil bagi masyarakat sistem pelayanan kesehatan tidak hanya menilai dan memfokus kepada pada tingka yang diberikan, tetapi juga bagaimana manfaat itu dilakukan pemerintah untuk melaksanakan pelayanan kesehatan.

Pada umumnya bahwa pelayanan kesehatan tidak hanya membatasidiri pada jasad manusia yangsakit akan tetapi juga memberikan perhatian sepenuhnya terhadap peningkatan pasien ke arah pemulian kesehatannya. Bahkan pelayanan kesehatan melangkah lebih baik lagi, yakin menjaga, memelihara, dan mempertahankan derajad kesehatan masyarakat. Demikian dengan pendekatan pelayanankesehatan yang menjadi comunisi opini saat ini ialah bukan hanya pelayanan, akan tetapi juga fungsi sosial dan segala bentuk keterkaitan kemanuasiaan seutuhnya, menjadi sasaran utamanya.

Pembangunan bidang kesehatan di Kabupaten Bantaeng diarahkan agar pelayanan kesehatan meningkat lebih luas, lebih merata, terjangkau oleh lapisan masyarakat kesehatan merupakan bagian yang terpenting dan diharapkan dapat menghasilkan derajat kesehatan yang lebih 
tinggi dan memungkinkan setiap orang hidup produktif secara sosial maupun ekonomis. Penyediaan sarana pelayanan kesehatan berupa rumah sakit, puskesmas dan tenaga kesehatan, semakin ditingkatkan jumlahnya sesuai dengan rencana pertahapannya, sejalan dengan itu penyediaan obat-obatan, alat kesehatan, pemberantasan penyakit menular dan peningkatan penyuluhan di bidang kesehatan.

Khusus tentang inovasi telah ada landasan hukumnya dalam UU No. 23 Tahun 2014 tentang Pemerintahan Daerah. Bertajuk Inovasi Daerah. Dari Pasal 386 hingga Pasal 390 UU 23/2014.Inovasi yang dimaksud dalam Pasal 386 adalah semua bentuk pembaharuan dalam penyelenggaraan pemerintahan daerah. Bentuk pembaharuan antara lain penerapan hasil ilmu pengetahuan dan teknologi dan temuan baru dalam penyelenggaraan pemerintahan. Kebijakan inovasi daerah mengacu pada prinsip : (1) peningkatan efisiensi; (2) perbaikan efektivitas; (3) perbaikan kualitas pelayanan; (4) tidak ada konflik kepentingan; (5) berorientasi kepada kepentingan umum; (6) dilakukan secara terbuka; (7) memenuhi nilai-nilai kepatutan; dan (8) dapat dipertanggungjawabkan hasilnya tidak untuk kepentingan diri sendiri,pemerintah Kabupaten Bantaeng mengeluarkan SK Nomor 1313/440 1.3.8/2010. Tentang 1.Meningkatkan status dan fungsi sarana pelayanan kesehatan dari puskesmas rawat jalan menjadi puskesmas inap. 2. Puskesmas rawat inap mempunyai punyai tugas melaksanakan program pelayanan kesehatan dasar, pelayanan rujukan dan pelayanan rawat inap. 3. Keputusan ini mulai berlaku pada tanggal yang ditetapkan dan apabila dikemudian hari terdapat keliruan didalamnya maka akan diadakan perbaikan sebagaimana mestinya.

Maka dari itu Pemerintah kabupaten bantaeng membuat kebijakan tentang pelayanan kesehatan 24 jam di Kebupaten Bantaeng, sebab menjadi kewajiban segenap jajaran pemerintah mulai dari daerah hingga ketingkat pusat untuk melakukan inovasi dalam pemberian layanan kesehatan yang mudah diakses oleh masyarakat, termasuk layanan mobile melalui kunjungan ke pasien-pasien yang membutuhkan layanan kesehatan, sebagaiamana yang selama ini telah dimplementasikan di Kabupaten Bantaeng, sejak di berlakukanya kebijakan tenatang pelayanan kesehatan 24 jam di kabupaten bantaeng.

Maka layanan dokter dengan berbagai peralatan standar international siap siaga selama 24 jam, masyarakat cukup menghubungi call center 113 saja, tim dokter dan perawat akan melakukan kunjungan kerumah-rumah masyarakat yang mengalami keluhan kesehatan, sifat layananyapun diberikan sesuai standar operasional apa perlu diselesaikan di tempat, di rujuk ke puskesmas rawat inap, dirujuk ke Rumah Sakit.Untuk itu saya mengambil judul penelitian ini agar saya mengetahui bagaimana Inovasi Pemerintah Dalam Pelayanan Kesehatan 24 jam di Kabupaten Bantaeng.

\section{A. Konsep Inovasi Pemerintah}

Inovasi adalah suatu penemuan baru yang berbeda dari yang sudah ada atau yang sudah dikenal sebelumnya.orang atau wirausahawan yang slalu berinovasi, maka ia dapat dikatakan sebagai seorang wirausahwan yang inovatif (Drucker. 2005:20).

Seseorang yang inovatif akan selalu berupaya melakukan perbaikan, menyajikan sesuatu yang baru/unik yang berbeda dengan yang sudah ada. inovatif juga merupakan sikap penting bagi yang hendaknya dimiliki oleh seorang wirausahawan. wirausahawan yang slalu melakukan inovasi dalam ushanya. maka keuntungan dan kesuksesan akan ia dapat. inovatif merupakan implikasi dari karakteristik wirausahawan yang mampu membawa perubahan pada lingkungan sekitarnya. inovatif secara tidak langsung menjadi sifat pembeda antara wirausahawan dengan orang biasa, maupun pengusaha. seorang wirausahawan akan selalu memikirkan untuk melakukan sesuatu yang berbeda, tidak seperti yang dipikirkan dan dilakukan 
oleh kebanyakan orang. kreatif dan inovatif adalah suatu kemampuan untuk memindahkan sumber daya yang kurang produktif menjadi sumber daya yang produktif sehingga memberikan nilai ekonomis. baik langsung maupun tidak langsung seorang wirausahawan adalah orang yangmampu membawa perubahan pada lingkunganya. disisi lain ia juga orang yang sanggup menerima perubahan yang terjadi dan menyikapi perubahan tersebut dengan positif. ia juga berani mengambil resiko berhasil ataupun gagal di setiap jalan yang ia ambil. wirausahawan mampu bertahan pada kondisi perekonomian yang sulit dan serba kalut. karena disaat semua resah, ia memiliki kreasi dan inovasi untuk memindahkan sumber daya yang kurang produktif menjadi sumber daya yang produktif sehingga memberikan nilai ekonomisDrucker. 2005:20)

Berdasarkan pengertian diatas, Robbins (2009: 55) lebih memfokuskan pada tiga hal utama yaitu : (1). Gagasan baru yaitu suatu olah pikir dalam mengamati suatu fenomena yang sedang terjadi, termasuk dalam bidang pendidikan, gagasan baru ini dapat berupa penemuan dari suatu gagasan pemikiran, Ide, sistem sampai pada kemungkinan gagasan yang mengkristal. (2). Produk dan jasa yaitu hasil langkah lanjutan dari adanya gagasan baru yang ditindak lanjuti dengan berbagai aktivitas, kajian, penelitian dan percobaan sehingga melahirkan konsep yang lebih konkret dalam bentuk produk dan jasa yang siap dikembangkan dan dimplementasikan termasuk hasil inovasi dibidang pendidikan. (3). Upaya perbaikan yaitu usaha sistematis untuk melakukan penyempurnaan dan melakukan perbaikan (Improvement) yang terus menerus sehingga buah inovasi itu dapat dirasakan manfaatnya.

Inovasi pemerintah menurut Pranada, 2003:14-16 adalah suatu hal yang sekarang ini sedang memasuki trend, sedangkan inovasi sendiri memiliki pengertian sebagai kemampuan pemimpin daerah untuk membuat sebuah terobosan dalam upaya meningkatkan kesejahteraan masyarakatnya, termasuk diantaranya kemampuan marketing dan promosi bagi daerah. Salah satu yang sedang bekembang belakang adalah adanya website pemerintah daerah yang interaktif, guna untuk memudahkan masyarakat mendapatkan informasi seputar pelaksanaan pemerintah daerahmelaksanakan transparansi hingga memudahkan pembayaran atas perizinan daerah.

Menurut Danim (2002, 43), Mendefinisikan,inovasisebagai suatu gagasan baru yang diterapkan untuk memprakarsai atau memperbaiki suatu produk atau proses dan jasa.inovasi adalah pengenalan ide baru yang berupa metode atau seperangkat komponen dalam kurikulum, Berdasarkan pengertian tersebut, Danim(2002, 43), memfokuskan pada tiga aspek inovasi yaitu :(1). Gagasan baru yaitu suatu olah pikir dalam mengamati suatu fenomena yang sedang terjadi, termasuk dalam bidang pendidikan, gagasan baru ini dapat berupa penemuan dari suatu gagasan pemikiran, ide, sistem sampai pada kemungkinan gagasan yang mengkristal. (2). Produk dan jasa yaitu hasil langkah lanjutan dari adanya gagasan baru yang ditindak lanjuti dengan berbagai aktivitas, kajian, penelitian dan percobaan sehingga melahirkan konsep yang lebih konkret dalam bentuk produk dan jasa yang siap dikembangkan dan dimplementasikan termasuk hasil inovasi dibidang pendidikan.. (3). Upaya perbaikan yaitu usaha sistematis untuk melakukan penyempurnaan dan melakukan perbaikan (improvement) yang terus menerus sehingga buah inovasi itu dapat dirasakan manfaatnya.

Menurut Ibrahim $(2006,56)$ adapun empat ciri-ciri inovasi sebagai berikut: (a). Memiliki kekhasan / khusus artinya suatuinovasimemiliki ciri yang khas dalam arti ide, program, tatanan, sistem, termasuk kemungkinan hasil yang diharapkan. (b). Memiliki ciri atau unsur kebaruan, dalam arti suatu inovasi harus memiliki karakteristik sebagai sebuah karya dan buah pemikiran yang memiliki kadar Orsinalitas dan kebaruan. (c). Program inovasi dilaksanakan melalui program yang terencana, dalam arti bahwa suatuinovasidilakukan melalui suatu proses yang yang tidak tergesa-gesa, namun keginovasi dipersiapkan secara matang 
dengan program yang jelas dan direncanakan terlebih dahulu. (d). Inovasi yang digulirkan memiliki tujuan, program inovasi yang dilakukan harus memiliki arah yang ingin dicapai, termasuk arah dan strategi untuk mencapai tujuan tersebut.

\section{B. Konsep Pelayanan Kesehatan}

Menurut UU No.36 Tahun 2009

tentang kesehatan, pada pasal 4-8 disebutkan setiap orang behak atas kesehatan, akses atau sumber daya, pelayanan kesehatan yang aman bermutu dan terjangkau, menentukan sendiri pelayanan kesehatan yang diperlukan, lingkungan yang sehat, info dan edukasi kesehatan yang seimbang dan bertanggung jawab, dan informasi tentang data kesehatan dirinya.

Pelayanan kesehatan menurut Notoatmojo (2002) adalah sebuah konsep yang digunakan dalam memberikan peleyanan kesehatan atau sebuah sub system peleyanan kesehatan yang tujuan utamanya adalah pelayanan prevetif (pencegahan) dan promotif (peningkatan) dengan sasaran masyarakat, atau uapaya yang dilakukan secara bersama sama atau sendiri dalam suatu organisasi untuk memelihara dan meningkatkan kesehatan, mencegah, dam menyembuhkan penyakit serta mememulihkan kesehatan seseorang, keluarga, kelompok, atau masyarakat.pelayanan kesehatan yang baik adalah bersifat wajar dan dapat diterima oleh masyarakat artinya pelayanan kesehatan tersebut dapat mengatasi masalah kesehatan yang dihadapi, tidak bertentangan dengan adat istiadat, kebudayaan, keyakinan, dan kepercayaan masyarakat serta bersifat tidak wajar,bukanlah suatu keadaan pelayanan kesehatan yang baik.

Pelayanan kesehatan menurut Levey dan Loomba yang dikutip dari Hilda Herdiani (2015), adalah setiap upaya yang akan meningkatkan kesehatan, mencegah dan menyembuhkan penyakit serta memulihkan kesehatan perseorangan, keluarga dan kelompok.

Menurut Somers dalam Azwar (2002) membagi pelayanan kesehatan yang menyeluruh dan terpadu kepada 2 (dua) jenis, yaitu: (1). Pelayanan kesehatan yang berhasil memadukan berbagai upaya kesehatan di masyarakat seperti pelayanan peningkatan dan pemeliharaan kesehatan,pencegahan, penyembuhan penyakit, serta pemulihan kesehatan. Dianggap terpadu bila mengandung kelima unsur ini.

(2). Pelayanan kesehatan yang menerapkan pendekatan menyeluruh. Jadi tidak hanya memperhatikan kesehatan penderita saja, akan tetapi juga memperhatikan keadaan sosial ekonomi, sosial budaya, sosial pysikologi dan lain sebagainya. Pendekatan tersebut dapat ditempuh dengan dua cara yaitu: (a). Pendekatan Institusi. Artinya penyelenggaraan kesehatan dilakukan dalam satu atap. Setiap jenis dan bentuk pelayanan kesehatan yang dibutuhkan dikelola dalam satu institusi kesehatan saja. (b) Pendekatan SistemAkibat kompleksnya pelayanan kesehatan, maka adalah mustahil untuk menyediakan segala bentuk dan jenis pelayanan dalam satu institusi, Karen terlalu mahal dan tidak efektif dan efisien.

Tjiptoherijanto (2008;9), umumnya dan pelayanan kesehatan khususnya, masyarakat sering dikatakan berada dalam keadaan membutuhkan,telah mencoba untuk membuat suatu kerangka pikir tentang siapakah yang sebenarnya mengatakan (melakukan), tentang apa (bagi) siapa. Formula Spek melibatkan tiga kelompok yaitu masyarakat, ahli medis, dan perorangan,atau Kebutuhan seseorang terhadap pelayanan kesehatan adalah sesuatu yang subjektif, karena merupakan wujud dari masalah-masalah kesehatan yang ada di masyarakat yang tercermin dari gambaran pola penyakit. Dengan demikian untuk menentukan perkembangan kebutuhan terhadap pelayanan kesehatan dapat mengacu pada perkembangan pola penyakit di masyarakat.

\section{Jenis Dan Faktor Pelayanan Kesehatan}

Menurut Winarsi (2007) jenis-jenis pelyanan kesehatan merupakan aktifitas ataun serangakaian alat yang bersifat tidak kasat mata (tidak dapat diraba), yang terjadi 
akibat interaksi antara konsumen atau karyawan atau hal-hal yang disediakan olah pemerintah dalam memeberi peleyanan.

Adapun Jenis-jenis pelayanan kesehatan menurut Levey (2004) : (a). Pelayanan kedokteran . Pelayanan kesehatan yang termasuk dalam kelompok pelayanan kedokteran (medical services) ditandai dengan cara pengorganisasian yang dapat bersifat sendiri atau secara bersama-sama dalam suatu organisasi tujuan utama untuk menyembuhkan penyakitdan memulijhkan kesehatan serta sasarannya terutama untuk perseorangan dan keluarga. (b). Pelayanan kesehatan masyarakat Pelayanan kesehatan yang termasuk dfalam kelompok kesehatan masyarakat yaitu ditandai dengan cara meningkatkan kesehatan masyarakat tujuan utamanya untuk mencegah penyakit dapat seseorang.

Faktor-faktor yamg mempengaruhi pelayanan kesehatan menurut Juanita (2008:23): (a). Pemikiran dan perasaan, berupa pengetahuan, persepsi, sikap, kepercayaan dan nilai-nilai seseorang terhadap objek dalam kesehatan. (b). Orang penting sebagai referensi, seseorang lebih banyak dipengaruhi oleh seseorang yang dianggap penting atau berpengaruh besar terhadap penggunan pelayanan kesehatan. (c). Sember-sumber daya, mencakup fasilitas,uang,waktu, tenaga, dan sebagaianya. Sumber-sumber daya yang berpengaruh terhadap perilaku seseorang atau kelompok masyarakat dalam memanfaatkan pelayanan kesehatan. (d). Kebudayaan, berupa norma-norma yang ada dimasyarakat dalam kaitannya dengan konsep pelayanan kesehatan.

(e). Ilmu pengetahuan dan teknologi baru, Mengingkat perkembanga ilmu pengetahuan dan teknologi, maka akan diikuti oleh perkembangan pelayanan kesehatan untuk mengatasi masalah penyakit-penyakit yang sulit dapat digunakan penggunaan alat seperti leser, terapi penggunaan gen dan lain-lain. (f). Nilai masyarakat. Dengan beragamnya masyarakat, maka dapat menimbulkan pemanfaatan jasa pelayanan kesehatan yang berbeda. Masyarakat yang sudah maju dengan pengetahuan yang tinggi, maka akan memiliki keasadaran yang lebih dalam pengunaan atau pemanfaatan jasa pelayanan kesehatan, demikian juga sebaliknya.

(g). Aspek legal dan etik. Dengan tingginya kesadaran masyarakat terhadap penggunaan atau pemanfaatan jasa pelayanan kesehatan, maka akan semakin tinggi pula tuntutan hukum dan etik dalam pelayanan kesehatan, sehingga pelaku pemberi pelayanan kesehatan harus dituntut untuk memberikan pelayanan kesehatan secara professional dengan memperhatikan nilai-nilai hokum dan etika yang ada di masyarakat. (h). Ekonomi. Semakin tinggi ekonomi seseorang, pelayanan kesehatan akan lebih diperhatikan dan mudah dijangkau, begitu juga sebaliknya, keadaan ekonomi ini yang akan dapat mempengaruhi dalam system pelayanan kesehatan. (i). Politik. Kebijakan pemerintah melalui system politik yang ada akan semakin berpengaruh sekali dalam system pemberian pelayanan kesehatan. Kebijakan-kebijakan yang ada dapat memberikan pola dalam sistem pelayanan.

\section{METODE PENELITIAN}

Jenis penelitian yang digunakan adalah kualitatif yaitu metode yang digunakan adalah penekanan pada observasi wawancara untuk orang, sebagai lawannya adalah gambaran kondisi objektif secara ilmiah, dimana peneliti adalah sebagai instrument kunci, teknik pengumpulan data dilakukan secara triangulasi analisis data bersifat induktif dan hasil penelitian kualitatif lebih menekankan makna daripada generalisasi.

Tipe penelitian ini adalah penelitian deskriptif kualitatif yakni suatu bentuk penelitian yang bertujuan memberikan gambaran umum berbagai macam data yang dikumpul dari lapangan secara objektif, sedangkan dasar penelitiannya adalah survey yakni tujuan dari penelitian deskriptif ini adalah menggambarkan mengenai situasi-situasi atau kejadiankejadian secara sistematis, factual dan akurat mengenai inovasi pemerintah daerah dalam pelayanan kesehatan 24 jam. 


\section{HASIL DAN PEMBAHASAN}

Pemerintah daerah untuk mengupayakan peningkatan kesejahteraan bagi masyarakatnya atau mencapai kemakmuran dan kesejateraan bagi masyarakat dan daerahnya inovasi program yang terbukti mampu membawa kemajuan bagi sebuah daerah yang sebelumnya terbelakang menjadi daerah yang maju secara ekonomi dan mampu meningkatkan kesejahteraan masyarakatnya. Di Indonesia istilah inovasi dalam konteks penyelanggaraan pemerintah mulai mengemukakan terutama sejak diberlakukannya kebijakan desentralisasi dan otonomi daerah tahun 2001 jumlah daerah giat mengembangkan inovasi dalam memperbaiki tata kelola pemerintahan, pelayanan publik, dan perbaikan iklim ekonomi.dan ada pun undangundang.Khusus tentang inovasi telah ada landasan hukumnya dalam UU No. 23 Tahun 2014 tentang Pemerintahan Daerah. Bertajuk Inovasi Daerah. Dari Pasal 386 hingga Pasal 390 UU 23/2014. Inovasi yang dimaksud dalam Pasal 386 adalah semua bentuk pembaharuan dalam penyelenggaraan pemerintahan daerah. Bentuk pembaharuan antara lain penerapan hasil ilmu pengetahuan dan teknologi dan temuan baru dalam penyelenggaraan pemerintahan.

\section{a. Inovasi Dalam Daerah Dalam Pelayanan Kesehatan 24 Jam Di Kabupaten Bantaeng}

Inovasi pemerintah daerah untuk mengupayakan peningkatan kesejahteraan bagi masyarakatnya atau mencapai kemakmuran dan kesejateraan bagi masyarakat dan daerahnya inovasi program yang terbukti mampu membawa kemajuan bagi sebuah daerah yang sebelumnya terbelakang menjadi daerah yang maju secara ekonomi dan mampu meningkatkan masyarakatnya.

\section{Aspek Efektivitas Dalam Inovasi Pemerintah Daerah}

Efektivitas adalah perubahan yang dinilai secara objektif dan berbagai kepentingan dalam perubahan suatu wilayah yang ditemukan, dan menunjukan sampai beberapa jauh mencapai tujuan yang lebih dahulu ditentukan atau sebarapa jauh target kualitas, dan waktu yang telah dicapai oleh pemerintah yang mana target sudah ditentukan terlebih dahulu dan selalu berusaha melakukan peningkatan terhadap pelayanan yang diberikan kepada masyarakat. Inovasi di bidang pelayanan publik merupakan ide kreatif teknologi atau cara baru dalam teknologi pelayanan atau memperbaharui yang sudah ada di bidang teknologi pelayanan atau menciptakan terobosan atau penyederhanaan di bidang peraturan pemerintah daerah.

\section{Pemerintah Daerah Dalam Inovasi Pemerintah}

Pembaharuan merupakan sesuatu yang baru atau ide baru yang merupakan segala sesuatu yang diciptakan dan dirasakan sebagai hal yang baru oleh manusia, seseorang, atau bahkan masyarakat sehingga dapat bermanfaat bagi kehidupan manusia atau masyarakat secara umum, Pembaruan dapat juga di katakan sebagai suatu ide atau hal-hal yang baru dalam suatu penemuan tertentu dilakukan atau diadakan untuk memecahkan masalah dan mengikuti aturan-aturan yang ada untu mencapai tujuan tersebut, Aparatur pemerintah mengeluarkan SK bupati nomor 1313/440 1.3.8/2010 tentang meningkatkan status dan fungsi sarana dari rawat jalan menjadi rawat inap atau bisa disebut pelayanan kesehatan 24 jam.

\section{Aspek Tingkat perubahan Dalam Inovasi Pemerintah Daerah}

Tingkat perubahan merupakan suatu yang dihasilkan penemuan baru dalam meningkatkan kinerja yang dipicu oleh inovasi pemerintah yang didasarkan pada masyarakat atau untuk pelayanan dan mendapatkan peningkatan dari yang sebelummnya, seperti halnya dalam bentuk pelayanan kesehatan pemerintah mengeluarkan kebijakan tentang pelayanan kesehatan 24 jam dalam pelayanan tersebut pasien yang setiap tahun meningkat pada tahun 2010 jumlah pasien ditangani sebanyak 10.632 penderita, pada tahun 2011 terjadi peningkatan menjadi 17.905 
penderita, tahun 2012 terjadi peningkatan menjadi 20.588 penderita, tahun 2013 dan 2014 berjumlah 30.571 penderita, itu dilihat dari berkembangnnya suatu wilayah atau bentuk pelayanannya baik dan memuaskan dari tingkat inovasi yang dilakukan yang di temukan oleh pemerintah yang setiap tahun meningkat karna bentuk pelayanan di Rumah Sakit tersebut efektif dan maksimal.

\section{Kepuasan masyarakat}

Kepuasan masyarakat adalah bagaimana cara pegawai dalam memberikan pelayanan kepada masyarakat atau pelanggan untuk memenuhi keinginan dan kebutuhan pelanggan dengan tujuan.meningkatkan kesejahteraan, sehingga masyarakat merasa puas dengan pelayanan yang telah diberikan, Pelanggan dalam hal ini pasien akan merasa puas jika mereka memperoleh pelayanan yang baik atau sesuai dengan yang diharapkan. pelayanan kesehatan yang dapat menimbulkan tingkat kepuasan pasien dapat bersumber dari faktor yang relatif seperti pelayanan rumah sakit, petugas kesehatan, atau pelayanan pendukung, peningkatkan kepuasan pasien adalah memperbaiki kualitas pelayanan dengan mendistribusikan pelayanan adil, palayanan yang ramah dan sopan, kebersihan, kerapian, kenyamanan dan keamanan ruangan serta kelengkapan, kesiapan dan kebersihan peralatan medis dan non medis

\section{b. Upaya Yang Dilakukan Dalam Pelayanan Kesehatan 24 Jam Di Kabupaten Bantaeng.}

Upaya pemerintah daerah untuk memberikan pelayanan kesehatan yang optimalkepada masyarakat dan menjadi sangat penting untuk dilakukan pelayanan kesehatan 24 jam di Kabupaten Bantaeng, pencapaian tujuan pembangunan kesehatan memerlukan kesadaran, kemauan dan kemampuan semua komponen bangsa untuk bersama-sama mewujudkan rakyat sehat.

Pelayanan kesehatan meliputi upaya kesehatan dan sumber dayanya harus dilakukan secara terpadu guna mencapai hasil yang optimal. Pembangunan kesehatan yang menyangkut upaya peningkatan kesehatan, pencegahan, penyembuhan penyakit, dan pemulihan kesehatan, harus dilaksanakan secara menyeluruh, pelayanan medis, keperawatan, rekam medis, pelayanan administrasi dan pelayanan penunjang umum.Rumah sakit sebagai salah satu instansi pelayanan kesehatan sebaiknya mampu memberikan pelayanan yang berkualitas dan bermutu serta dapat memuaskan setiap jasa pelayanan rumah sakit yang diselenggarakan sesuai standart dan kode etik profesi.

Indikator upaya pemerintah (1).Aturan (2).Fasilitas. Demikian halnya dalam upaya pemerintah dalam pelayanan kesehatan dikabupaten Bantaeng yang akan dideskripsikan melalui beberapa indicator diatas yang tampak berikut.

\section{Aturan Dalam Pelayanan Kesehatan}

Ketentuan yang digunakan untuk mengatur pegawai atau pasien untuk mentaati aturan yang baik, jika tidak terdapat peraturan bisa bertindak sewenang-wenang tanpa kendali dan sulit di atur, dan adanya aturan bantuk keputusan Bupati Nomor 1313/440.1.3.8/2010 yang harus ditaati peraturan agar semua menjadi teratur dan orang akan merasa nyaman dan aturan harus dilakukan atau tidak boleh tidak dilakukan.

\section{Fasilitas Dalam Pelayanan Kesehatan}

Segala sesuatu yang dapat dimudahkan dapat dilancarkan pelaksanaannya dan dapat melancarkan suatu pelayanan tersebut, fasilitas fisik suatu yang mempunyai peran dan memudahkan, jadi dalam hal ini fasilitas dapat disamakan dengan sarana yang dilayani fasiliatas perawatan kesehatan yang di khususkan untuk perawatan pasien. Fasilitas dalam pelayanan kesehatan sesuatu yang dapat membantu memudahkan dalam pekerjaan, tujuan, dan sebagainya,fasilitas merupakan

\section{PEMBAHASAN}

\section{Aspek Efektivitas Dalam Inovasi Pemerintah Daerah}

Dari hasil wawancara diatas penulis dapat simpulkan bahwa dalam melakukan perubahan dalam pelayanan kesehatan 
terutama dalam pelayanan kesehatan 24 jam harus lebih efektif lagi agar masyarakat merasa puas dimana pemerintah sudah memberikan atau menyiapkan program pelayanan kesehatan 24 jam dengan adanya BSB yang siap menjemput masyarakat meskipun berada dipelosok desa.

Dari hasi uraian diatas penulis dapat menyimpulkan bahwa, dalam melakukan perubahan dalam pelayanan kesehatan 24 jam harus lebih efektif lagi agar masyarakat merasa puas, dimana pemerintah sudah menyiapkan Brigade Siaga Bencana (BSB) yang siap menjemput masyarakat yang membutuhkan, dan tidak membedabedakan satu sama lain dengan melayani pasi

\section{Aspek Pembarauan Dalam Inovasi Pemerintah Daerah \\ Dari hasil uraian wawancara} diatas,penulis dapat menyimpulkan bahwa, pemerintah dalam memberikan pelayanan kesehatan 24 jam pemerintah sudah mempunyai undang-undang atau permenkes, petugas dalam melayani masyarakat sudah mengikuti aturan yang sudah ditetapkan oleh pemerintah setempat dan masyarakat sudah dilayani dengan baik serta sarana dan prasarananya yang teratur.

\section{Aspek Tingkat perubahan Dalam Inovasi Pemerintah Daerah}

Apa yang telah dilkukan pemerintah dalam memberikan kebijakan untuk pelayanan kesehatan 24 jam dimana sebelumnya sampai jam kerja saja dan saat ini pemerintah setempat mendapatkan peningkatan dan sudah terlaksana dengan baik, karena masyarakat diberikan pelayanan 24 jam dengan begitu masyarakat merasakan tingkat perubahan dalampelayanannya, kualitas pelayanan seperti yang dikatakan oleh responden kepuasan masyarakat ini merupakan tujuan untuk mencapai yang diinginkan oleh masyarakat setempat dan dapat dipenuhi dengan baik.

\section{Kepuasan masyarakat}

Pemahaman perawat membantu dalam proses pelayanan kesehatan atau yang lainnya. masyarakat merasa puas terhadap paelayanan kesehatan 24 jam yang di kabupaten Bantaeng. Sebagaimana hasil tanggapan dari masyarakat menunjukan hasil berada pada tanggapan yang cukup baik, kepuasan terhadap suatu pelayanan rumah sakit yang baik merupakan cerminan bahwa rumah sakit tersebut dapat memberikan pelayanan kesehatan yang berkualitas layanan oleh suatu instansi kepada masyarakat untuk memenuhi keinginan dan kebutuhan masyarakat dengan tujuan untuk meningkatkan kesejahteraan sehingga masyarakat merasa puas dengan pelayanan yang diberikan dengan adanya Brigade Siaga Bencana (BSB) yang disiapkan oleh pemerintah, masyarakat dengan cepat bisa dilayani .

\section{PENUTUP}

Berdasarkan penelitian yang telah dilakukan, maka penulis menyimpulkan sebagai berikut: 1.Bentuk inovasi dalam pelayanan kesehatan 24 jam dapat disimpulkan bahwa, pada tahapan perumusan masalah inovasi pemerintah daerah sudah berjalan dengan lancar karena perubahan dalam pelayanan kesehatan sudah efiktif, pemerintah sudah menyiapakan program pelayanan kesehatan 24 jam sesuai dengan undangundang atau permenkes, dan msyarakat sudah mengikuti aturan yang dikeluarkan oleh pemerintah setempat. (2). Upaya yang dilakukan pemerintah dalam pelayanan kesehatan 24 jam yaitu menyediakan saran dan prasaran berupa alat dan bahan agar masyarakat merasa puas terhadap apa yang diberikan oleh pemerintah setempat, dapat dilihat dari call center layanan kesehatan 24 jam, ambulans serta dokter keluarga yang siap sedia menolong masyarakat kapanpun dibutuhkan., BSB melakukan kegiatan terpadu layanan kesehatan dengan melibatkan 20 dokter, delapan perawat dan ditunjang lima unit ambulance hingga ke pelosok desa, sebagai pemerintah memberikan kebijakan dalam pembentukan Brigade Siaga Bencana untuk mengatasi kondisi masyarakat yang memerlukan perawatan namun terkendala transportasi, terutama pada malam hari, Kemudian pemerintah Bantaeng mengupayakan pembentukan layanan kesehatan 24 jam yang tak hanya 


\section{Jumal lemial \\ MUQODDIMAH}

melakukan layanan terhadap kecelakaan, namun juga masyarakat yang menderita penyakit, meski berada di pelosok desa Ada pun saran- saran yaitu: (1). Pelayanan pada rumah sakit Anwar Makkatutu perlu ditingkatkan, berupa ketepatan waktu dalam melayani pasien yang membutuhkan. (b). Kepada pihak pemerintah yakni Dinas Kesehatan masih perlu meninjau kembali atau melakukan pengawasan terhadap kinerja pegawai rumah sakit yang melaksanakan pelayanan kesehatan 24 jam.

\section{DAFTAR PUSTAKA}

Azwar, Muh, 2005, Pelayanan Kesehatan.: Yogyakarta:Pusat Study Reformasi Pelayanan Public.

Drucker, Peter, 2007, Political Innovation Pemerintah Daerah: Jakarta.

Depertemen Pendidikan Dan Kebudayaan Jakarta: Bumi Aksara

Juanita, R, 2008, PelayananKesehatan Di Indonesia: Arogya

Levely, 2008, Etika Pelayanan Kesehatan: Jakarta: PT Gunung Agung.

Mahsyar, A. (2011). Masalah Pelayanan Publik di Indonesia dalam Perspektif Administrasi Publik. Otoritas: Jurnal IImu Pemerintahan, 1(2).

Muhammadiah, M. (2011). Reformasi Pelayanan Publik Sebagai Strategi Mewujudkan Good Governance. Otoritas: Jurnal Ilmu Pemerintahan, 1(2).

Robbins stevens, 2009. Teori Organisai. Jakarta: Erlangga.

Pradana, riga, 2003, Organizational Inovasi Pemerintah Pelayanan Publik: Semarang

Tjiptoherijanto, 2008, Pelayanan Umum Kesehatan Dan Bermutu: Bandung

\author{
Winarsi, 2007, Pelayanan Kesehatan \\ Masyarakat: Jakarta: Ghalia \\ Indonesia \\ Undang-Undang No. 36 Tahun 2009 \\ Tentang Pelayanan Kesehatan Pasal \\ 4-8
}

